\title{
Ecological and economic security as a factor of sustainable rural development
}

\author{
$N L$ Kurepina $^{1, *}, N B$ Berikova $^{1}, M V$ Shovaeva $^{1}$, and $D V$ Mandzhieva $^{1}$ \\ ${ }^{1}$ Kalmyk State University. after B.B/ Gorodovikova, Elista
}

\begin{abstract}
Today, in the 21 st century, our society rapidly exhausts natural resources without care for the preservation of the environment. The dependence on the environmental factor in such sectors of the economy as the agricultural one that thoroughly depends on natural resources, became decisive, and this cannot be ignored when assessing the development of the territory, including the territory of the Russian Federation. In this work, the author considers the problem of ensuring environmental safety in a market economy and proves that it is primarily associated with the emergence of threats and risks of environmental and economic security. The author has proposed mechanisms for the sustainable development of agricultural production and concluded that environmental and economic security should be considered as a single system of interaction between the ecosphere, sociosphere and technosphere.
\end{abstract}

\section{Introduction}

The modern development of society is characterized by significant external environmental impacts, dependence on the environmental factor in such sectors as agrarian, in the production of which natural resources are involved has become decisive and it is impossible not to take it into account when assessing the development of the territory. These territories include the Republic of Kalmykia, the main industry of which is agricultural production, largely dependent on natural factors.

The main part of the rural areas of Kalmykia is located in the arid zone, which is characterized by high environmental stress, largely affected by various adverse meteorological phenomena that have a detrimental effect not only on the development of agro-industrial production, but also on the living conditions of the population.

In the National Security Strategy of the Russian Federation until 2020 (2009), the strategic objectives of ensuring environmental safety and rational nature management are:

-preservation of the environment and ensuring its protection; - elimination of the environmental consequences of economic activity in the context of increasing economic activity and global climate change. Therefore, understanding the inevitability of environmental consequences, it is necessary to carefully consider economic decisions, take into account environmental and economic threats and take measures to neutralize them.

\section{Problem Statement}

The problem of ensuring environmental safety in a market economy is undoubtedly a topic. This is primarily due to the emergence of threats and risks of environmental and economic security, as evidenced by the data of the study.

\section{Research objectives and research questions}

Conduct a comprehensive analysis of modern approaches to the problems of environmental and economic security, identify threats to the environmental and economic security of development and assess their impact on the level of sustainable development of rural areas of the Republic of Kalmykia.

The study of the relationship between environmental management and economic development was carried out in their works by scientists from various branches of knowledge, economists, soil scientists, physicians, etc. Among them are V.N. Vernadsky (2009), V.V. Dokuchaeva (1951), V. A. Timiryazev (1948) and others. They argued that the increasing demand for natural resources leads to increased environmental impact, a deepening environmental crisis, and an aggravation of socio-economic problems.

One of the earliest can be considered a theory developed by J. Odum. As he remarked: "When" the science of home "(Ecology) and the science of" housekeeping "(Econo-mica) merge, and when the subject of Ethics expands its boundaries and includes, along with the values produced by man, the values

\footnotetext{
${ }^{*}$ Corresponding author: kurepinanl@mail.ru
} 


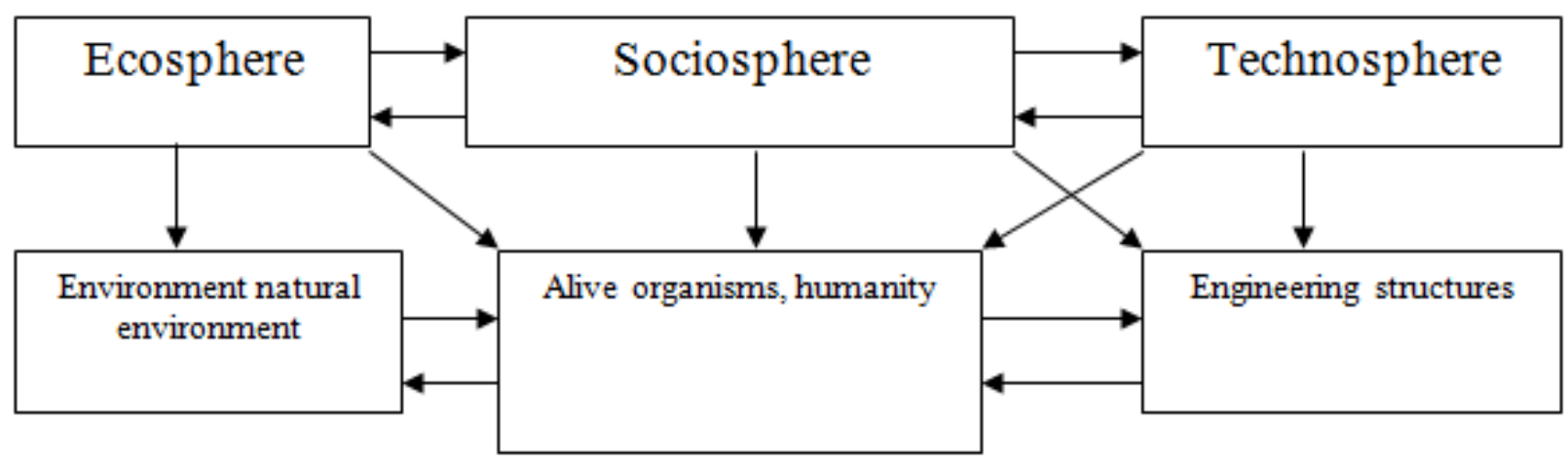

Fig. 1. The relationship of objects and elementsenvironmental and economic security.

created by the environment, then we can actually become optimists about the future of humanity. " (Y. Odum, 1986)

Currently, there is no single approach to the definition of the concept of environmental safety, some consider it as a structural element of economic security (V.K. Senchagov, 2005; G.S. Vechkanov, 2007; V.A. Bogomolov 2012, etc.), others only environmental problems of the environment (V. Danilova-Danilyan, 2005; S.N. Bobylev, 2007, etc.)

An interesting approach N.N. Skeeter (2017), who believes that the economic basis of regional ecologicaleconomic interests is the ownership of natural resources, and the ecological basis is the integrity of the ecosystems of the region.

\section{Methods}

In the course of the study, the methods of economic analysis were used: comparisons, indicative, groupings, expert, etc. Indicators were used that represent the threshold values of threats to environmental and economic security. The method based on the calculation of weighted average values for each group of indicators was used to determine republican indicators compared with the average Russian and regional indicators.

\section{Received data}

A review of theoretical sources allowed us to systematize and identify the main elements of the system of ecological and economic security and came to the conclusion that ecological and economic security should be considered as a single system of interaction between the ecosphere, the sociosphere and the technosphere that can ensure sustainable development. The study of the ecological and economic security of both natural and other types of threats and risks of the territory of the Republic of Kalmykia has led us to this definition. In the course of the study, we studied the factors influencing the level of security, objects, threats, and other indicators of environmental and economic security. The impact factors were considered as positive, that is, having a positive impact on the ecological situation and destructive, having a destructive impact on the environment: natural, man-made and anthropogenic.

We considered ecological and economic security as a single system, interrelations of the ecosphere, the sociosphere and the technosphere (fig. 1).

The study revealed the interrelation of objects and elements of ecological and economic security, it was determined that individual elements can be inherent in different objects, so humanity is an integral element of both the ecosphere and the sociosphere, and the natural environment can also be attributed to different stages of transformation. to the ecosphere and the technosphere, depending on the degree of transformation.

This approach allowed us to systematize the threats in terms of impact objects, so the threats of ecological and economic security, the object of which are ecosystems, we considered by type of natural resources: land, water and biological and identify the most important for the Republic of Kalmykia (fig. 2).

The main resource important for the economic development of the region is land, of the total land area of the Republic of Kalmykia - 6,932.2 thousand hectares or $92.8 \%$. relate to agricultural land, the most exposed to destructive factors.

Failure to cultivate arable land, cultivating monocoles, overloading livestock, plowing pastures and other factors led to the development of destructive processes such as dehumification, salinization, desertification, etc.

In some places, irreversible environmental degradation has gone so far that they have become unsuitable for life and economic activity.

Recently, there has been concern about the dynamics of reduction in productive areas, agricultural land in the Russian Federation has decreased by almost 20.0 million hectares, arable land by 16.0 million hectares, which is also characteristic of the Republic of Kalmykia.

Of a total of 824.1 thousand hectares of arable land, only a third is cultivated, the area of acreage in the farms of all categories in 2015 is 263.1 thousand hectares, the unused arable land is overgrown with weeds and degraded.

We carried out a study of the threats of environmental and economic security to the object of 


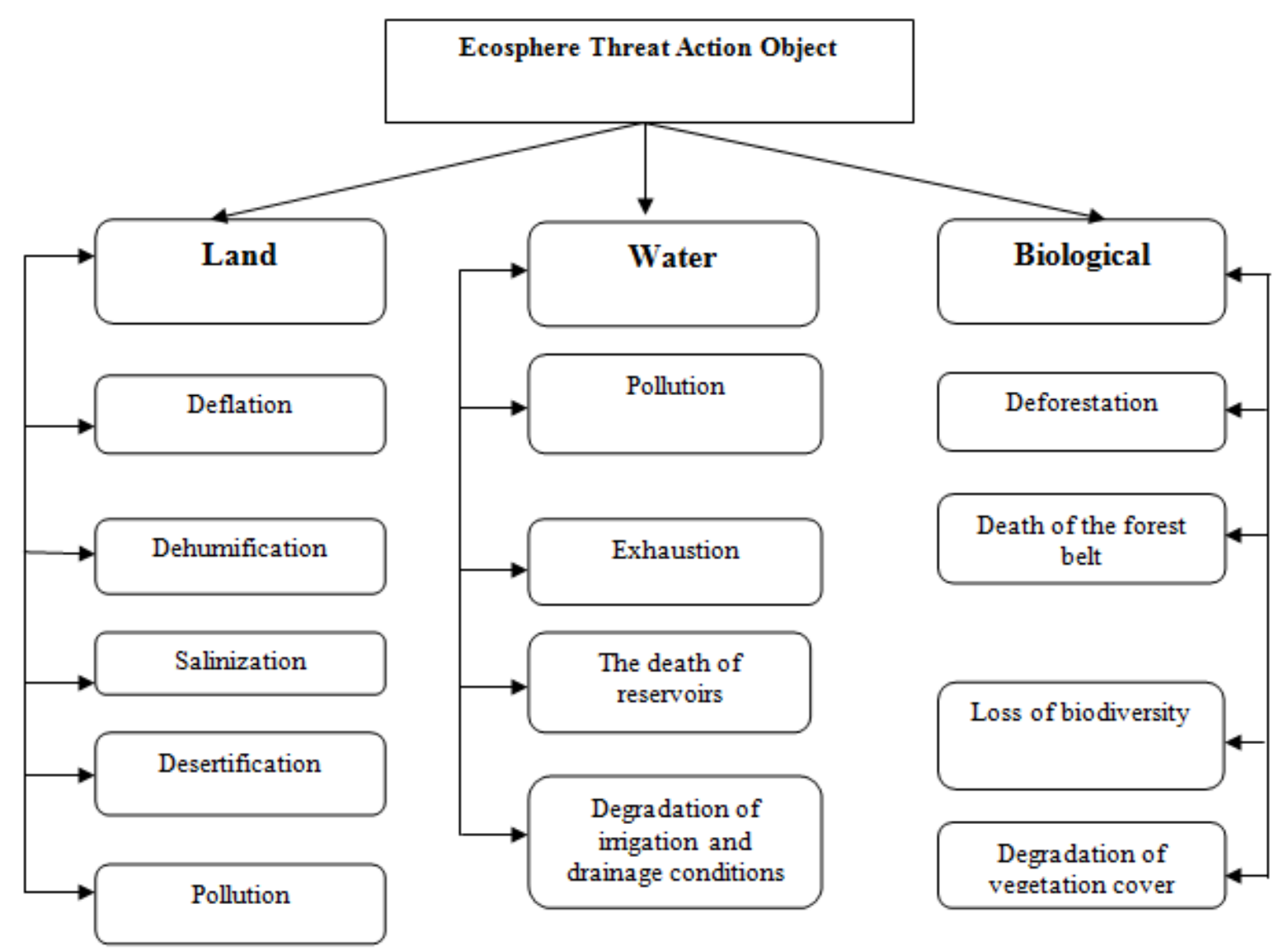

Fig. 2. Ecosphere - threats to environmental and economic security.

impact on the sociosphere in several directions. The main ones are shown in fig. 3 .

The water supply and quality of drinking water is of particular concern. In rural settlements of the Republic of Kalmykia, more than half of the sources used do not comply with sanitary and epidemiological rules and regulations.

Drinking water consumed by the population of Kalmykia does not meet the requirements in half of cases due to its high salinity from $0.6-10 \mathrm{~g} / 1$, high content of sulphates, chlorides, iron salts and hardness within 10-12 mg / eq / 1 .

Low level of consumption, below the rational nutritional norms for the main groups of nutrients are alarming.

Despite the positive dynamics of the consumption of basic foodstuffs, for certain types it is significantly lower than the rational norm: meat and meat products $-86.9 \%$, milk and dairy products $-43.5 \%$, eggs $-41.1 \%$.

With actual water consumption - $421 /$ day per one rural resident at a rate of 125-160 1/ day. Water quality also does not meet sanitary and epidemiological standards for the level of salinity from $0.6-10 \mathrm{~g} / \mathrm{l}$ and hardness $10-12 \mathrm{mg} / \mathrm{eq} / 1$.

The problem of food safety in Russia has acquired particular urgency at the present stage of economic development, which is reflected in the Strategy. $(1,2009)$

The provision of high-quality and safe goods and services is related to the strategic goals of ensuring national security in the area of improving the quality of life of Russian citizens.

Of particular concern is the low level of per capita consumption of protein products: meat and meat products, milk and dairy products, fish, eggs, despite the fact that in recent years there has been a positive trend in their consumption. Despite the positive dynamics of consumption of basic foodstuffs, for certain types of consumption is significantly lower than the norms and makes up in $\%$ of the rational norm: meat and meat products, $86.9 \%$, milk and dairy products $-43.5 \%$, eggs $41.1 \%$.

Consumption of other types of products also decreased, so bread consumption fell to the norm- $81.6 \%$, vegetables $-55.5 \%$, sugar $-53.2 \%$.

Especially important is the observance of rationally balanced nutrition for children, if for an adult it is health, longevity, high performance, then for children it is normal development, physical and mental health for the whole future life. The decrease in consumption of basic foodstuffs by the population of Kalmykia has affected the energy value of food.

Not only has the energy and nutritional value of the products consumed changed, but also its structure, the consumption of fats has increased, which leads to pathology - obesity, and such important nutrients as proteins are consumed significantly less than the rational nutrition standard $-61.1 \%$. 


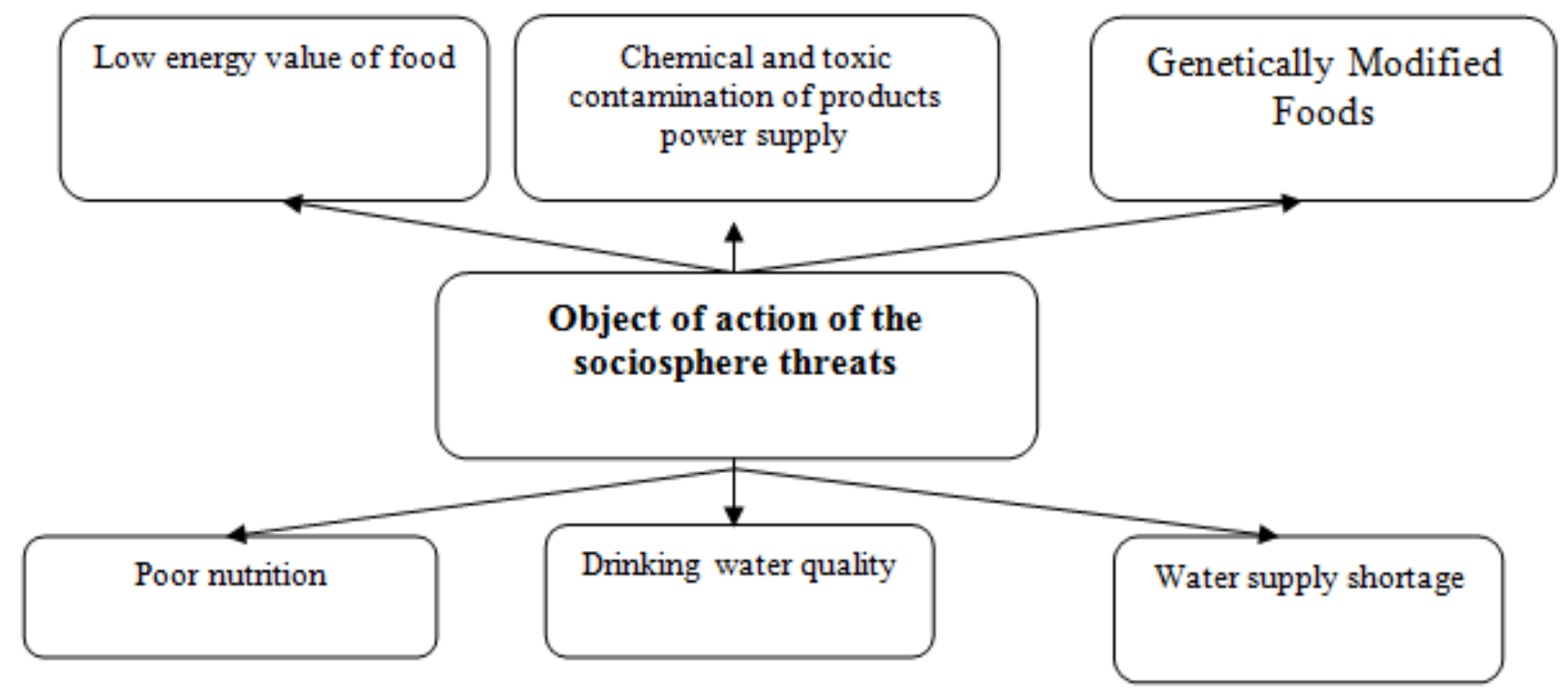

Fig. 3. Sociosphere - threats to environmental and economic security.

The lack of a balanced diet is one of the reasons for the occurrence of nutritionally-related diseases among the population, such as rickets, anemia, food intolerance, including food allergies.

Pollution and degradation of the environment, malnutrition and poor-quality products are increasingly affecting people's health every year.

The incidence of individual classes of diseases increased by two or more times, the incidence of diseases due to the endocrine system, organs of the circulatory system, and neoplasms, diseases of the blood and blood and digestive organs increased significantly.

The incidence of individual classes of diseases has increased two or more times, the incidence of diseases of the endocrine system, organs of the circulatory system, due to neoplasms, diseases of the blood and bloodforming organs and digestive organs has increased significantly.

To assess the ecological and economic security of the region, an integral indicator of the level of environmental and economic threats is proposed, calculated by determining the impact of positive and negative factors on the resulting indicator of regional development - the gross regional product, which is calculated using the formula proposed and validated by multi-criteria evaluation. This integral indicator includes indicators of nature intensity, land intensity, damage intensity, resource intensity, energy intensity, waste intensity.

To assess threats to the sociosphere:

- provision of complete food;

- drinking water supply, thousand m3 / person;

- population incidence per 100,000 population;

- mortality per 100,000 population.

An integrated environmental and economic indicator will allow a comprehensive assessment of the degree of sustainability of objects of environmental and economic security.

\section{Conclusion}

Assessment of the ecological and economic security of the main element of ecosystems - land resources showed that the development and involvement of marginal lands of the Republic of Kalmykia in agricultural circulation led to a violation of the sustainability of natural ecosystems, the impossibility of their self-regulation and balance, ensuring the constancy of the productivity of landscape components. All this requires an environmental approach to environmental management and land use in combination with economic interests.

The main tool in the implementation of these tasks should be the state land management, focused on the environmentally balanced use of land, regulation of land relations through economic mechanisms. We consider the following to be the main areas of ensuring ecological and economic security in the Republic of Kalmykia:

- land management and landscape planning;

- introducing an environmental imperative to use rockbreaking and resource-depleting technologies;

- transition to ecological and economic systems of agricultural production;

- improvement of technologies from the standpoint of greening and energy saving;

- expansion of the network of protected areas;

- improvement of land reclamation state through a complex of conservation measures.

- legislative regulation of environmental and economic security.

The proposed mechanisms for the sustainable development of agricultural production in arid regions in the context of market relations are aimed at increasing the sustainability of agricultural production, restoring lost agricultural potential, as well as reducing the negative impact on fragile arid agricultural landscapes. Disadvantage in the field of environmental management 
is not only related to the state of ecosystems, but also to the society living in this territory, which allows to conclude that environmental and economic security should be considered as a single system of interaction between the ecosphere, sociosphere and technosphere that can ensure the sustainable development of rural areas.

The article was prepared with the support of the Russian Federal Property Fund in the framework of the project No. 19010-00796 "Improving the methodology for assessing the economic security of a poly-ethnic region: an interdisciplinary approach.

\section{References}

[1] Presidential Decree of 12.05.2009, no. 537, "On the Strategy of the National Security of the Russian Federation until 2020", reference system Guarantor.

[2] Presidential Decree of 13.05.2017, no. 208, "On the Strategy of the National Security of the Russian Federation until 2030", reference system Guarantor.

[3] V.A. Bogomolov, N.D. Eriashvili, E.N. Barikayev, Economic security (M.: Unity-Dana, 2012).

[4] V.A. Bogomolov, N.D. Eriashvili, E.N. Barikayev, Economic security (M.: Unity-Dana, 2012).

[5] V.I. Vernadsky, The biosphere and the noosphere (Moscow: IRIS-press, 2009).

[6] G.S. Vechkanov, Economic security (SPb.: Peter, 2007).

[7] A.E. Gorodetsky, Economic Security of Russia: New Strategy in New Realities (2018) [Electronic resource].

Available

at: https://elibrary_31228401_54672830.pdf.

[8] V.I. Danilov-Danilyants, K.S. Losev, I.E. Reif, Before the main challenge of civilization: a view from Russia (M.: Infra-M, 2005).

[9] V.V. Dokuchaev, Transformation of the nature of the steppes (M.-L.: Publishing House of the Academy of Sciences of the USSR, 1951).

[10] N.L. Kurepina, On some problems of the formation of sustainable development of regional socio - ecological - economic systems, Bulletin of the Kalmyk Scientific Center of the Russian Academy of Sciences, 136-141 (2017).

[11] N.L. Kurepina, Yu.S. Bogzykov, et al., Sustainable development of rural areas as a factor of economic security (Elista: APP Djangar, 2009).

[12] U. Odum, Ecology (M.: World, 1986).

[13] V.K. Senchagov, et al., Economic Security of Russia (M.: Business, 2005).

[14] V.A. Timiryazev, Selected Works (M.: OGIZ Selkhozgiz, 1948).

[15] Site of the Federal State Statistics Service [Electronic resource]. Available at: http://www.gks.ru.
[16] N. Skiter, A.F. Rogachev, T.I. Mazaeva, Modeling Ecological Security, Mediterian Journal of Social Science, 6, 3 S, 185-192 (6 June 2015). 